\title{
TLR4 Influences Hepatitis B Virus Related Hepatocellular Carcinoma by Regulating the Wnt/ $\beta$-Catenin Pathway
}

\author{
Yuanqin Yin ${ }^{a} \quad$ Fei Lib Songlin $\mathrm{Li}^{\mathrm{c}} \quad$ Jingjing Caid ${ }^{\mathrm{d}} \quad$ Jing Shie ${ }^{\mathrm{Y}}$ Youhong Jiang ${ }^{\mathrm{a}}$ \\ aCancer Institute, First Affiliated Hospital, China Medical University, Shenyang, ${ }^{b}$ Department of \\ Internal Medicine, The Tumor Hospital of Liaoning Province, Shenyang, 'Department of Respiratory \\ Medicine, Tangshan Worker Hospital, Tangshan, 'General Hospital of Fushun Mining Bureau, Fushun, \\ eDepartment of Obstetrics and Gynecology, The Tumor Hospital of Liaoning Province, Shenyang, China
}

\section{Key Words}

TLR4 $\bullet$ Wnt/ $\beta$-catenin pathway $\bullet \mathrm{HCC} \bullet \mathrm{HBV}$

\begin{abstract}
Background/Aims: We investigated the correlation between toll-like receptor 4 (TLR4) and $\beta$-catenin for disclosing the potential pathogenesis of hepatocellular carcinoma (HCC). Methods: Immunohistochemical toolkit was implemented to measure the expression of TLR4 and $\beta$-catenin in 98 cases of HCC tissues and adjacent tissues. After setting up the HepG2.2.15 hepatitis $B$ virus (HBV) related HCC cell line, we divided the cells into the control group, TLR4 siRNA group, $\beta$-catenin siRNA group, and pcDNA.3.1 TLR4 + $\beta$-catenin siRNA group. Western blot, CCK-8 method, Transwell and flow cytometry were used to detect protein expression, cell proliferation, cell migration and invasion as well as cell apoptosis, respectively. Nude mice tumor model was established to observe the effects of TLR4 and $\beta$-catenin on the progression of HBV-related HCC in vivo. Results:The positive rates of TLR4 and $\beta$-catenin were higher in HCC tissues compared with normal tissues. Both the TLR4 siRNA group and $\beta$-catenin siRNA group exhibited a decreased expression of $\beta$-catenin. The proliferation, migration and invasion of tumor cells in the above two groups were suppressed, while the cell apoptosis appeared to be stimulated. As suggested by the results from in vivo and in vitro experiments, the up-regulation of TLR4 could antagonize the corresponding effect of $\beta$-catenin siRNA. Conclusions: TLR4 can affect the expression of $\beta$-catenin and hence influence the progression of HBV-related HCC.

\section{Introduction}

Hepatocellular carcinoma (HCC) is a fatal malignant tumor which causes a large number of deaths. More than 20,000 new cases were diagnosed with liver cancer in the United States and approximately half a million new HCC cases were identified each year in the world [1]. In developing countries, about $85 \%$ of liver cancer patients are associated with the hepatitis 
B virus (HBV) infection [2]. HCC is known as a chemo-resistant cancer which cannot be cured by using cytotoxic drugs [3]. No effective systemic therapies for HCC patients have been developed [4] because the pathogenic mechanism of HCC is highly complicated, mainly including the over-activation of Ras/Raf/MEK/ERK, PI3K/AKT/mTOR signaling pathways and the abnormal expression of receptor tyrosine kinases [5-7]. The complexity of HCC pathogenesis indicates that new therapeutic targets should be developed to overcome this challenge.

Toll-like receptors (TLRs) in immune cells can act as key pattern recognition receptors (PRRs) [8]. TLRs participate in the regulation of both innate and adaptive immune responses and they have been investigated in various diseases such as allergic and infectious diseases [9-11]. It has also been reported that TLRs, which are associated with the biological activities of cancer cells, are expressed in different tumor cells. For example, the abnormal expression of toll-like receptor 4 (TLR4, the receptor of lipopolysaccharide which is observed from gram-negative bacteria) in cancer cells induces both tumor growth and escapes from immune surveillance [12]. Clinical research indicated that high levels of plasmatic endotoxin may trigger liver inflammation via TLRs activation which may act as a tumor promoter in the intestine [13]. Previous research has verified that TLR4 is an essential element for the progression of HCC which is reflected by stimulating proliferation, hepatomitogen epiregulin expression and apoptosis resistance [14]. Therefore, TLR4 may be selected as a therapeutic target for preventing and treating HCC effectively.

On the other hand, Wnt/ $\beta$-catenin signaling pathway is involved in a variety of cell processes including cell proliferation, differentiation and embryonic development [15]. $\beta$-catenin is an important signal transducer molecule which is stabilized when it is combined with T cell factor/lymphocyte-enhancing factor (TCF/LEF) through nuclear translocation [16]. As suggested by an increasing number of studies, the abnormal activation of Wnt/ $\beta$ catenin signaling is linked with various cancer cells [17]. Moreover, both HCC initiation and progression are associated with the unusual activation of Wnt/ $\beta$-catenin signaling pathway [18]. Clinical statistics indicate that aberrant $W n t / \beta$-catenin signaling is usually accompanied with oncogenic activation which is commonly observed in HCC patients [19]. Another study clarified that TLR4 may synergize with Wnt/ $\beta$-catenin pathway and such interaction may be associated with the progression of colorectal cancer (CRC) [20]. As a result, we aim to assess whether the abnormal expression of TLR 4 or $\beta$-catenin is involved in the progression of HCC, thereby revealing their potential molecular functionality.

The influence of TLR4 and Wnt/ $\beta$-catenin pathway on HBV-related HCC was explored both in vitro and in vivo. We demonstrate that tumor cell proliferation can be activated by over-expressing TLR4 or Wnt/ $\beta$-catenin pathway. Thus, potential anti-tumor mechanism of TLR4 and $\beta$-catenin may be revealed by our study, which can be used to discover alternative targeted therapies for HCC patients.

\section{Materials and Methods}

\section{Samples}

The corresponding $98 \mathrm{HBV}$ related HCC tissues and adjacent normal tissues included in our experiments were acquired from First Affiliated Hospital, China Medical University from January 2015 to May 2016. Initial treatment for patients was liver resection. All patients did not receive any preoperative treatment. Informed consent had been obtained from all patients, and the research protocols have been approved by the Ethics Committee of First Affiliated Hospital, China Medical University.

Histology and Immunohistochemistry

After tissues were fixed in $10 \%$ formalin, they were embedded and cut into 5-mm-thick slices in paraffin. Subsequently, slices were dewaxed and rehydrated. 3\% hydrogen peroxide buffer and heated $10 \mathrm{mM}$ citrate buffer were used for antigen restoration before immunological reaction. After stained 


\section{Cellular Physiology Cell Physiol Biochem 2017;42:469-479 \begin{tabular}{ll|l} 
DOI: 10.1159/000477594 & O 2017 The Author(s). Published by S. Karger AG, Basel \\
www.karger.com/cpb
\end{tabular}}

Yin et al.: Impact of TLR4 on the Development of HBV-Related HCC

with diaminobenzidine (DAB) and hematoxylin solution, slices were dehydrated and sealed. Anti-TLR4 was purchased from Novus Biologicals. Also, catenin (anti- $\beta$-catenin, Sigma-Aldrich) was detected for mammalian species.

\section{Cell Culture and Transfection}

HCC cell lines (HepG2.2.15, MHCC97-H, and Hep3B) were obtained from the Institute of Biochemistry and Cell Biology of Shanghai. The culture medium containing Dulbecco modified eagle medium (DMEM), $100 \mathrm{U} / \mathrm{mL}$ penicillin, $0.1 \mathrm{mg} / \mathrm{mL}$ streptomycin and $10 \%$ fetal bovine serum was placed in a $37^{\circ} \mathrm{C}, 5 \% \mathrm{CO}_{2}$ humidified incubator. G418 (6.5 mg/mL, Solarbio, Shanghai, China) was added to maintain HCC cells. The pcDNA.3.1 TLR4, TLR4 siRNA and $\beta$-catenin siRNA recombinant plasmid vectors were purchased from Ribobio (Shanghai, China). Lipofectamine 2000 (Invitrogen, MA, USA) was used to transfect the corresponding plasmids into cells based on the manufacturer's instruction. Transfected cells were collected for mRNA and protein expression analysis after 24 and 36 hours' incubation, respectively. After that, samples were divided into four groups: negative control group (blank carrier transfected), TLR4 siRNA group (TLR4 siRNA transfected), $\beta$-catenin siRNA group ( $\beta$-catenin siRNA transfected) and pcDNA.3.1 TLR4 $+\beta$-catenin siRNA group (pcDNA.3.1 TLR4 and $\beta$-catenin siRNA transfected).

\section{Western blot}

Lysis buffer [50 mmol/L Tris- $\mathrm{HCl}(\mathrm{pH} 8.0$ ), $150 \mathrm{mmol} / \mathrm{L} \mathrm{NaCl}, 0.1 \%$ SDS, and $5 \mathrm{mmol} / \mathrm{L}$ EDTA (pH 8.0)] was prepared for the following experiment. After cells were treated by precooling phosphate buffer saline (PBS), but before transferred into the EP tube, protease inhibitors and RIPA lysis were added for the purpose of complete lysis. The supernatant after centrifugation $\left(4^{\circ} \mathrm{C}, 15 \mathrm{~min}\right.$, and $\left.15000 \mathrm{r} / \mathrm{min}\right)$ was stored at $-80^{\circ} \mathrm{C}$. Protein samples of $20 \mathrm{~g}$ was added to each hole and separated by $12 \%$ SDS-polyacrylamide gel electro-phoresis and then transferred to polyvinylidene difluoride membranes (Millipore, Billerica, MA, USA) which were subject to antibody reaction (internal reference $=$ GAPDH). TLR4 antibody (Protein tech Wuhan, China), $\beta$-catenin antibody (Protein tech, Wuhan, China) and GAPDH antibody (Abcam, USA) (dilution concentration were 1:400, 1:500, 1:900, respectively) were used in this study. Membranes were blocked with $5 \%$ fat-free milk and then incubated with primary antibodies at $4{ }^{\circ} \mathrm{C}$ overnight, followed by the incubation with secondary antibodies for two hours.

\section{Cell Counting kit-8 (CCK-8) Assay}

Cells were cultured in 96 well plates, in which each hole contained 3000-5000 cells and they were cultured for 24, 48, 72 and 96 hours. Cells were allowed for adhesion for a period of 12 hours and were starved with serum-free medium for another 12 hours. Subsequently, cells were exposed to $10 \mu \mathrm{g} / \mathrm{mL}$ LPS for different durations. Once the incubation with CCK-8 (Zomanbio, China) had been carried out for three hours, the corresponding optical density (OD) values were detected at $450 \mathrm{~nm}$.

\section{Cell Migration and Invasion Assay}

The migration status of cells was detected using Transwell assay which was conducted in the Transwell chambers. The invasion status of cells was detected in the upper chamber after the gel predation. In order to cover the upper surface of the Transwell cell membranes, DMEM was used with dilute matrigel (1:8). Then $250 \mu \mathrm{L}$ cell suspension was added to each upper well, while medium with $10 \%$ fetal calf serum was added into the lower one and hatched in a $5 \% \mathrm{CO}_{2}$ incubator at $37^{\circ} \mathrm{C}$. After each Transwell chamber containing $1 \times 10^{5}$ cells had been cultured for 48 hours, cells in the lower chambers were collected and suspended in non-serum media which contained $0.1 \%$ crystal violet. Then the number of cells was counted under a microscope, and ten fields were randomly selected to count the cell number on the membrane surface. Finally, the corresponding mean value is calculated to represent the invasion status.

\section{Cell Apoptosis}

Cell apoptosis rate was analyzed using flow cytometry. Annexin V-PE/7AAD (BD Bio Sciences, USA) was used to detect the cell apoptosis based on the manufacturer's instruction. Cells were seeded at the density of $1 \times 10^{5}$ cells per well in the 9-well plates. Cell apoptosis rate was analyzed using the Cell Apoptosis Analysis Kit (Multi Sciences, China). Stained samples were examined by flow cytometry.

\section{KARGER}




\section{Cellular Physiology Cell Physiol Biochem 2017;42:469-479 \\ \begin{tabular}{l|l} 
DOI: 10.1159/000477594 & Ond Biochemistry 2017 The Author(s). Published by S. Karger AG, Basel \\
wwww.karger.com/cpb
\end{tabular}}

Yin et al.: Impact of TLR4 on the Development of HBV-Related HCC

Nude Mouse Tumorigenesis Assay

Male nude BALB/C mice about four weeks old (Shanghai Experimental Animal Center) were selected for the formation of subcutaneous tumor using HCC cells. Twenty mice were randomly divided into 4 groups (control group, TLR4 siRNA group, $\beta$-catenin siRNA group, and pcDNA.3.1 TLR4+ $\beta$-catenin siRNA group) and were inoculated subcutaneously with $2 \times 10^{6}$ HCC cells (with different transfections) in the lateral axillary fossa, with an accumulated dose of $1 \times 10^{8} \mathrm{TU}$. Tumor growth was observed and recorded every seven days (using the formula $V=0.52 * \mathrm{~d}^{3}$ for volume estimation, $\mathrm{d}$ : tumor diameter). Mice were sacrificed four weeks after the inoculation.

\section{Statistical Analysis}

SPSS 21.0 (IBM SPSS for Windows, Version 21.0; IBM Corporation, Armonk, NY, USA) was used to analyze all the data. Data from different groups were compared using the paired t-test. The Analysis of Variance (ANOVA) was carried out for comparing data from multiple groups. The correlation coefficient between TLR4 and $\beta$-catenin was quantified by Kappa correlation coefficient. $P<0.05$ represents a significant difference.

\section{Results}

The expression of TLR4 and $\beta$-catenin

The cytoplasm and (or) cell membrane stained tan or brown were considered as positive expression of TLR4 in cells. In addition, the cytoplasm, cell membrane and (or) nuclear were stained as tan or brown granules in $\beta$-catenin positive cells. Every 10 random horizons were seen in each section (100 cells/horizon) under a microscope (Abcam, Cambridge, MA, USA), and when the rate of positive cells is equal or greater than $5 \%$, the tissue is judged as positive. Cells without brown dye particles or the positive rate is less than $5 \%$, the tissue is viewed as negative. The specific semi-quantitative classification of TLR4 and $\beta$-catenin was shown in Table 1 . Then, we also compared the proportion of positive TLR4/ $\beta$-catenin expression between carcinoma and normal tissues. As shown in Fig. 1, there is a significant difference in the proportion of positive TLR4/ $\beta$-catenin expression between cancerous and adjacent tissues $(P<0.05)$. Moreover, the expression of TLR4 and $\beta$-catenin in tumor tissues are higher than that in adjacent tissues $(\mathrm{P}<0.05)$. Three different human HCC cell lines (HepG2.2.15, MHCC97-H, and Hep3B) and normal liver cell line were detected for the expression levels of TLR4 and $\beta$-catenin. TLR4 was significantly overexpressed in all HCC cell lines, whereas it was significantly under-expressed in the normal liver cell line (Fig. 2). As Fig. 3 showed, the expression of TLR4 decreased significantly in the TLR4 siRNA group compared with the control group $(P<0.05)$. No significant difference in the TLR4 protein expression was observed in the $\beta$-catenin siRNA and control group $(P>0.05)$. However, the protein level of TLR4 increased significantly after the transfection of pcDNA.3.1 TLR4 $(P<0.05)$. The transfection of TLR4 siRNA and $\beta$-catenin siRNA can significantly downregulate the expression of $\beta$-catenin, while the over-expression of TLR4 is able to elevate the expression of $\beta$-catenin significantly $(P<0.05)$.

TLR4/ $\beta$-catenin affects the proliferation, migration, invasion and apoptosis of tumor cells

Tumor cell proliferation assessed using CCK-8 assay was compared among different groups (Fig. 4). TLR4 siRNA transfection and $\beta$-catenin siRNA transfection can significantly inhibit the proliferation of tumor cells in comparison with the control group whereas the over-expression of TLR4 is also able to stimulate the proliferation of tumor cells at $24 \mathrm{~h}$,

Table 1. Semi-quantitative Classification of TLR 4 and $\beta$-catenin.,+++ and +++ : The tissue is positive expression

\begin{tabular}{lcccc}
\hline Classification & - & + & ++ & +++ \\
\hline The rate of TLR4 positive cells & $<5 \%$ & $6 \%-25 \%$ & $26 \%-50 \%$ & $>50 \%$ \\
The rate of $\beta$-catenin positive cells & $<5 \%$ & $6 \%-25 \%$ & $26 \%-75 \%$ & $>75 \%$ \\
\hline
\end{tabular}



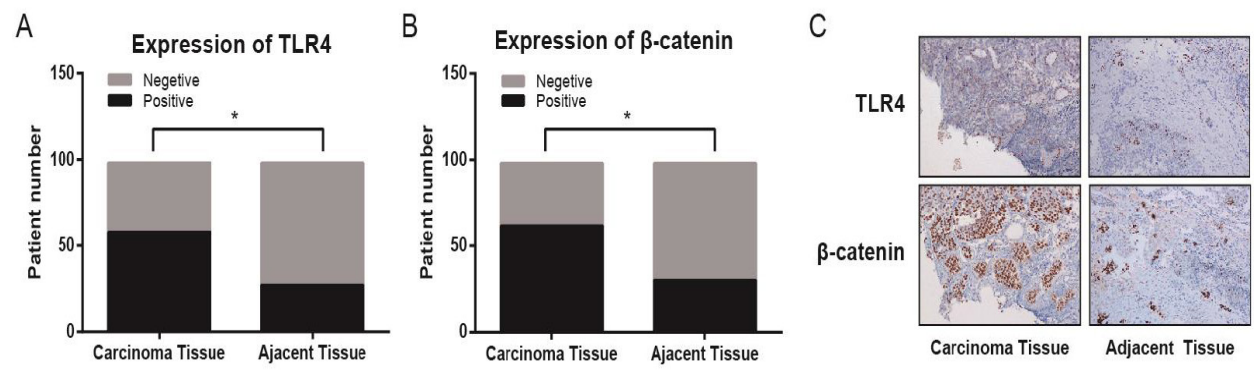

Fig. 1. Expressions of TLR4 and $\beta$-catenin in HBV related HCC tissues and adjacent tissues. (A-B) The positive rate of TLR4 (A) and $\beta$-catenin (B) in $98 \mathrm{HBV}$ related HCC tissues and adjacent tissues. (C) The expression of TLR4 and $\beta$-catenin in tumorous tissues and adjacent tissues. HBV: hepatitis B virus, HCC: hepatocellular carcinoma. * means $P<0.05$.

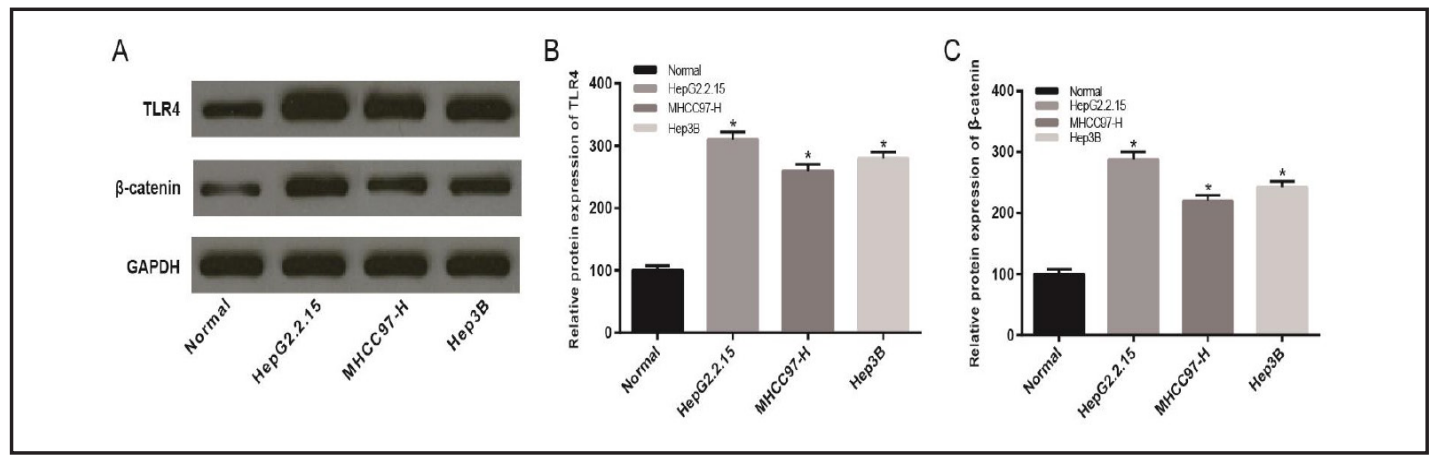

Fig. 2. Expressions of TLR4 and $\beta$-catenin in normal liver cells and three different HCC cell lines. (A) Western blot analysis of TLR4 and $\beta$-catenin expression in the normal liver cell line and three different HCC cell lines. (B-C) Quantitative protein levels of TLR4 and $\beta$-catenin in cells. Data were presented as mean \pm SD. ${ }^{*} P<0.05$ versus control group.

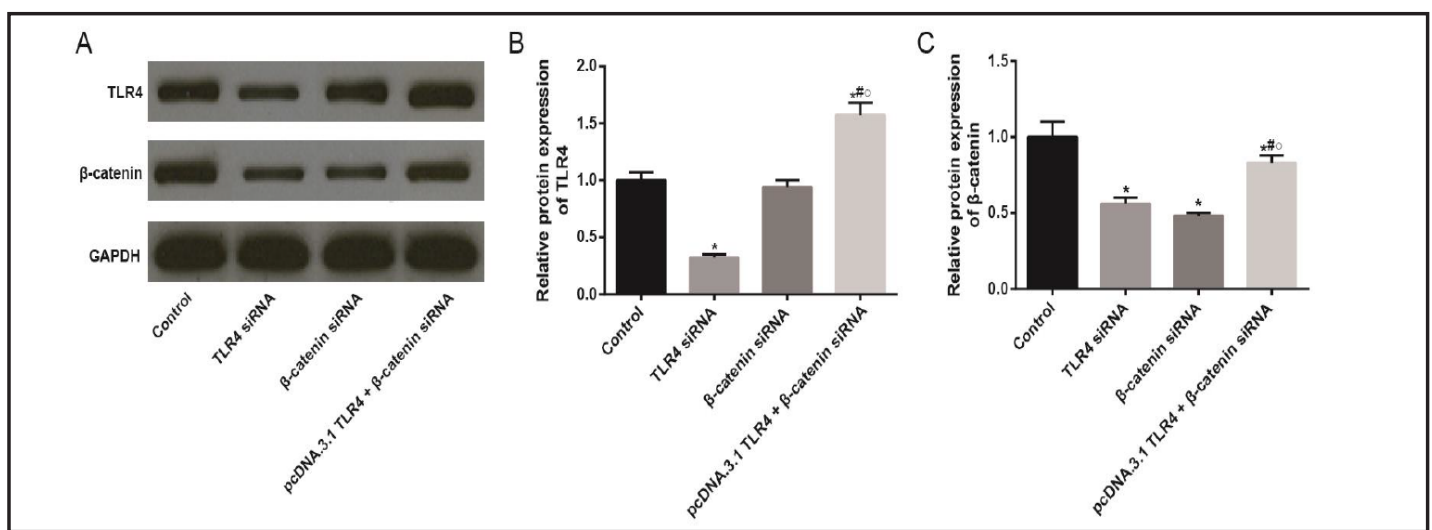

Fig. 3. Expressions of TLR4 and $\beta$-catenin in cells after transfection. (A) Western blot analysis of TLR4 and $\beta$-catenin expression in different groups of cells (i.e. control, TLR4 siRNA, $\beta$-catenin siRNA and pcDNA.3.1 TLR4 + $\beta$-catenin siRNA) with GAPDH as the internal control. (B-C) Quantitative protein levels of TLR4 and $\beta$-catenin in cells. Data were presented as mean \pm SD for three independent experiments. ${ }^{*} P<0.05$ versus control group, ${ }^{\#} P<0.05$ versus TLR4 siRNA group, ${ }^{\circ} P<0.05$ versus $\beta$-catenin siRNA group.

48h, $72 \mathrm{~h}$ and $96 \mathrm{~h}(P<0.05)$, respectively. The proliferation rate in the pcDNA.3.1 TLR4 $+\beta$-catenin siRNA group was lower than that in the control group from $24 \mathrm{~h}$ to $96 \mathrm{~h}$, but significantly higher than that in the TLR4 siRNA and $\beta$-catenin siRNA group at $72 \mathrm{~h}$ and $96 \mathrm{~h}$ 
Fig. 4. Effects of TLR4 siRNA, $\beta$-catenin siRNA and TLR4 on the proliferation of HCC cells estimated by the CCK- 8 assay. Data were presented as mean \pm SD for three independent experiments. ${ }^{*} P<0.05$ versus control group, ${ }^{\#} P<0.05$ versus TLR4 siRNA group, ${ }^{\circ} P<0.05$ versus $\beta$-catenin siRNA group.
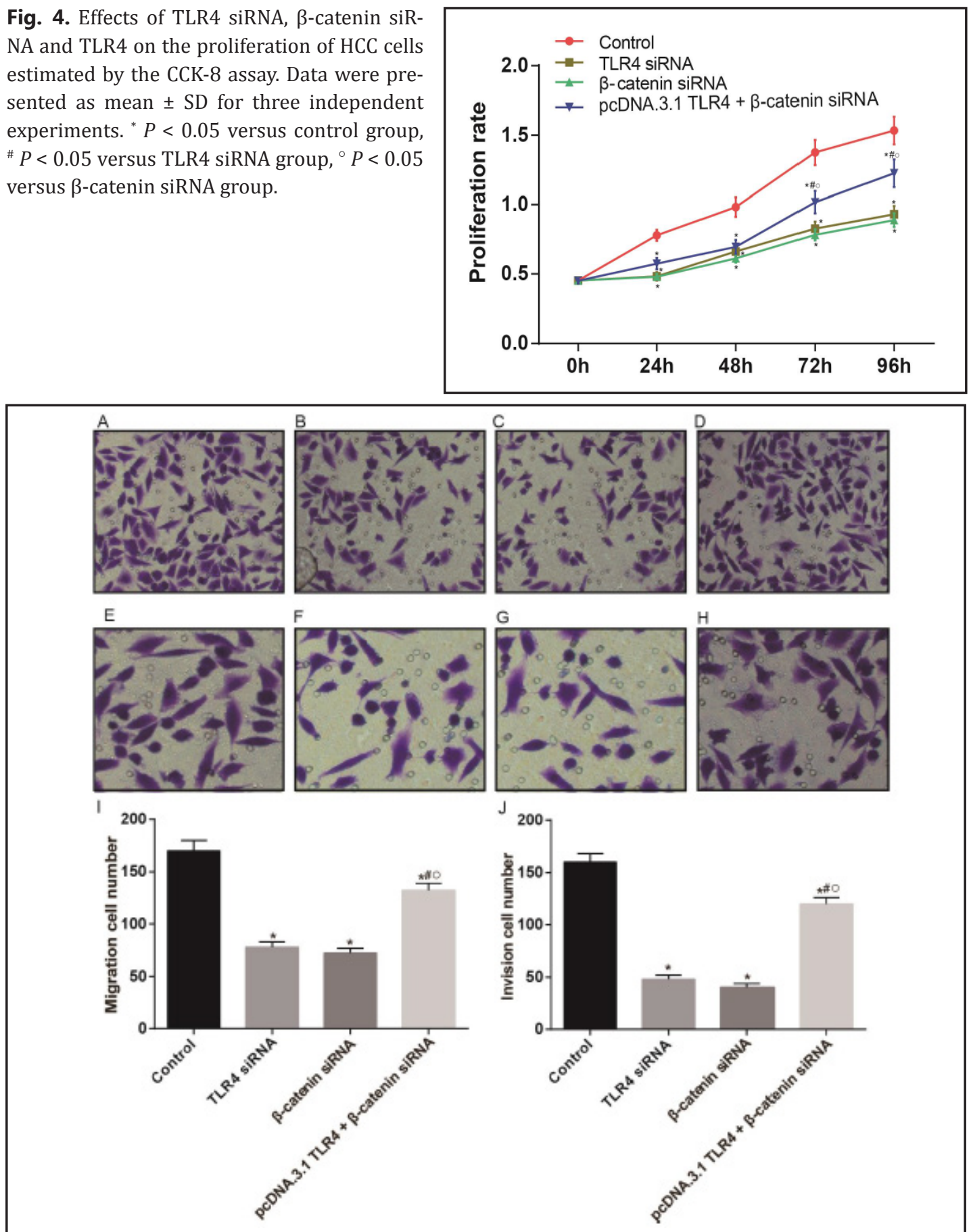

Fig. 5. Migration and invasion status of cells estimated by Transwell experiments. (A-D) The number of cells that penetrated the inserted membrane in groups of control (A), TLR4 siRNA (B), $\beta$-catenin siRNA (C) and pcDNA.3.1 TLR4 + $\beta$-catenin siRNA (D). $(\mathrm{E}-\mathrm{H})$ The number of cells that penetrated the membrane with gel in groups of control (E), TLR4 siRNA (F), $\beta$-catenin siRNA (G) and pcDNA.3.1 TLR4 + $\beta$-catenin siRNA (H). (I) Migratory cell numbers in each group. (J) Invaded cell numbers in each group. Data were presented as mean \pm SD for three independent experiments. ${ }^{*} P<0.05$ versus control group, ${ }^{\#} P<0.05$ versus TLR4 siRNA group, ${ }^{\circ} P<0.05$ versus $\beta$-catenin siRNA group.

$(P<0.05)$. In addition, no remarkable difference was observed between the TLR4 siRNA and $\beta$-catenin siRNA group at $24 \mathrm{~h}, 48 \mathrm{~h}, 72 \mathrm{~h}$ and $96 \mathrm{~h}$ separately $(P>0.05)$. Moreover, the

\section{KARGER}




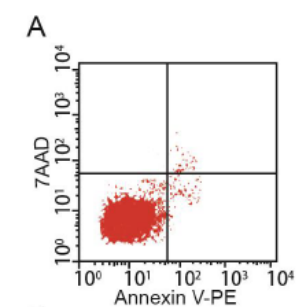

C

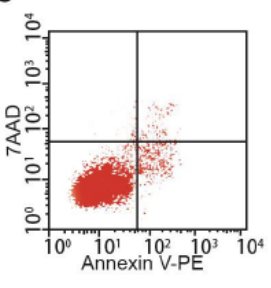

B

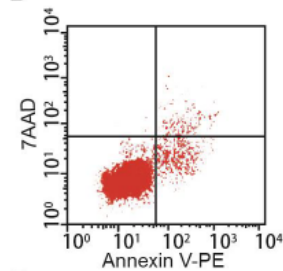

D

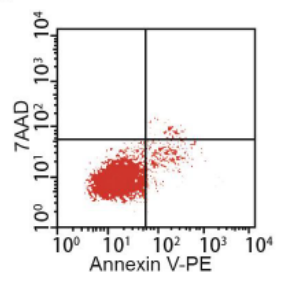

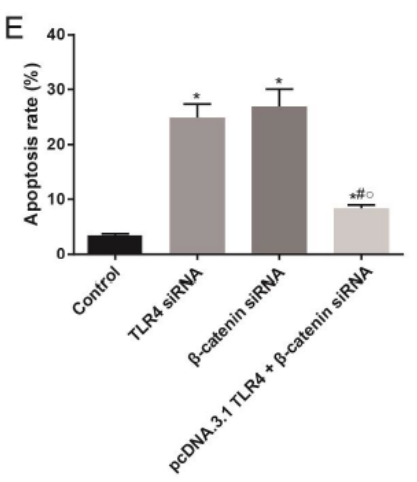

Fig. 6. Apoptosis rate of cells in each group estimated by flow cytometry. (A-D) Distribution of apoptotic cells in groups of control (A), TLR4 siRNA (B), $\beta$-catenin siRNA (C) and pcDNA.3.1 TLR4 + $\beta$-catenin siRNA (D). (E) The corresponding apoptosis rate of cells in each group. Data were presented as mean \pm SD for three independent experiments. ${ }^{*} P<0.05$ versus control group, ${ }^{\#} P<0.05$ versus TLR4 siRNA group, ${ }^{\circ} P<0.05$ versus $\beta$-catenin siRNA group.

Fig. 7. Effects of TLR4 siRNA, $\beta$-catenin siRNA and TLR4 on tumor volume (A) and tumor weight (B) in vivo. Data were presented as mean \pm SD for three independent experiments. ${ }^{*} P$ $<0.05$ versus control group, \# $P<0.05$ versus TLR4 siRNA group, ${ }^{\circ} P<0.05$ versus $\beta$-catenin siRNA group.
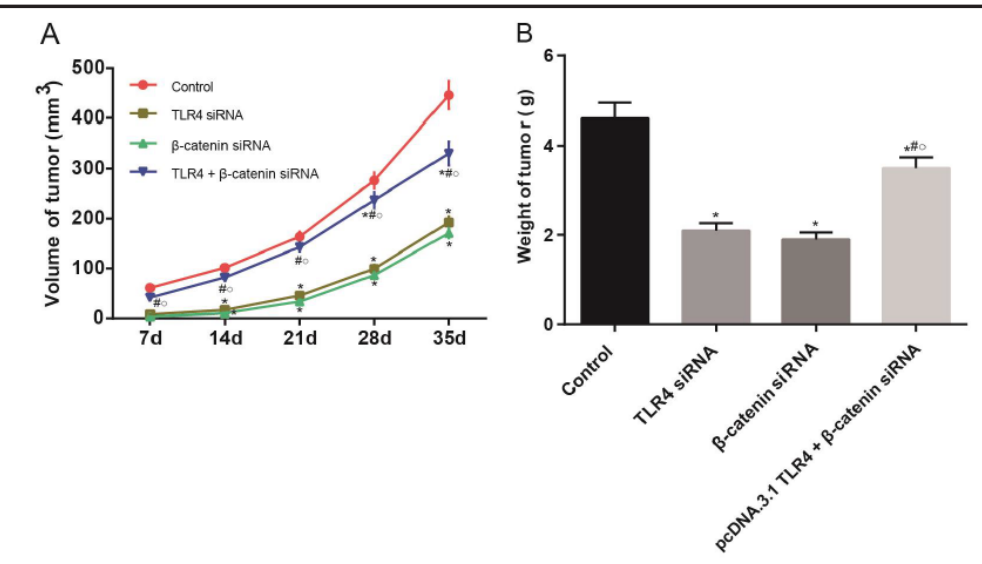

corresponding results of Transwell experiment which evaluated cell migration and invasion status were displayed in Fig. 5. Compared with the control group, cell migration and invasion in the TLR4 siRNA and $\beta$-catenin siRNA groups were significantly reduced $(P<0.05)$. The over-expression of TLR4 up-regulated the cell migration and invasion of HepG2.2.15. Furthermore, the number of migrated and invaded cells in the pcDNA.3.1 TLR4 + $\beta$-catenin siRNA group was significantly lower than that in the control group, but higher than that in the TLR4 siRNA and $\beta$-catenin siRNA groups $(P<0.05)$. Cell apoptosis status in the above four groups were detected and compared using the flow cytometry (Fig. 6). The apoptosis rates in the TLR4 siRNA and $\beta$-catenin siRNA groups were significantly higher than that in the control group. The apoptosis rate in the pcDNA.3.1 TLR4 + $\beta$-catenin siRNA group was higher than that in the control group but lower compared with the TLR4 siRNA and $\beta$-catenin siRNA group $(P<0.05)$. Therefore, the over-expression of TLR4 may reduce cell apoptosis through the pathway which is related to $\beta$-catenin.

\section{Results from animal model}

Tumor cells were injected into the four groups of mice by using hypodermic. Mice were continued to be fed for a period of four weeks after tumor was visible on the 7 th day. Then, 
Yin et al.: Impact of TLR4 on the Development of HBV-Related HCC

the volume and weight of tumor were both measured. As shown in Fig. 7, the tumor growth rate and the final weight of tumors in the TLR4 siRNA and $\beta$-catenin siRNA groups were significantly decreased compared with the control group. Besides, the tumor growth rate in the pcDNA.3.1 TLR4 + $\beta$-catenin siRNA group was significantly lower than that in the control group after 21 days but higher than that in the TLR 4 siRNA and $\beta$-catenin siRNA groups at each measurement timing point $(P<0.05)$. The above results are consistent with those of in vitro experiments.

\section{Discussion}

HCC is featured by the high recurrence rate as well as high tumor metastasis rate [21, 22]. The long-term survival status of HCC patients has not been improved since current approaches are not able to cure this disease [23]. HCC is usually accompanied by chronic inflammatory states due to cirrhosis and chronic hepatitis which may result from hepatitis $\mathrm{B} / \mathrm{C}$ virus or non-viral-correlated factors including alcohol consumption and obesity [24]. Moreover, it is believed that the immune microenvironment of HCC may influence the proliferation, migration, and invasion of cancer cells [25].

TLRs belong to transmembrane signaling receptors that luxuriantly express in immune cells [26]. TLR4 is a member of the TLR family which can induce the production of IL, IFN, TNF- $\beta$ and other inflammatory factors by both activating multiple transcription factors and regulating several downstream proteins such as IKB kinase and mitogen activated protein kinase (MAPK) [27, 28]. The imbalance of TLR4 has been discovered in several human tumors including gastric cancer, colorectal cancer and non-small cell lung cancer [29-31] and such an imbalance is associated with the development and progression of tumors. For example, $\mathrm{Li}$ et al. reported that the down-regulation of TLR4 could inhibit the progression of human nonsmall cell lung cancer (NSCLC) [32]. Also Yuan et al. indicated that the up-regulation of TLR4 stimulated gastric cancer cell growth through inducing the production of mitochondrial reactive oxygen species and activating both Akt and NF- $\mathrm{BB}$ signaling pathways [33]. On the other hand, a colorectal carcinoma model constructed on mice suggested that constitutively active TLR4 may inhibit tumor load by inducing apoptosis [34]. Therefore, we suspected that there appears to be a sophisticated link between TLR4 and tumor.

As suggested by a recent research, the expression of TLR4 is up-regulated in HBVrelated cirrhosis and HCC [35] and TLR4 appears to have a significant role in HCC [36]. For instance, both Wang et al. and Gu et al. showed that the activation of TLR4 signaling induced by lipopolysaccharide (LPS) could promote the development of HCC [37, 38]. Jing et al. discovered that the expression level of TLR4 in HCC tissues was higher than that in normal liver tissues and the activation of LPS-TLR4-NF- $\kappa B$ signaling pathway which is mediated by TLR4 is associated with the development of HCC [39]. In our study, the expression level of TLR4 in HCC tissues was consistent with the above discovery. Furthermore, our study revealed that the down-regulated TLR4 induced cell apoptosis and inhibited the proliferation, invasion and immigration of HepG2.2.15 cells. This tendency was confirmed in in vivo studies which indicated that TLR4 modulated HBV-related HCC. Likewise, Dapito et al. suggested that TLR4 stimulated the proliferation and suppressed the apoptosis, thus influenced the progression of HCC [14].

$\beta$-catenin is a protein molecule which is encoded by the CTNNB1 gene. CTNNB1 gene is a key factor for the Wnt/ $\beta$-catenin signaling pathway which is potentially able to modulate tumor progression. Besides, the Wnt/ $\beta$-catenin signaling pathway plays an important role in the E-cadherin/catenin complex which is potentially able to preserve adhesion between cells [40-42]. More importantly, it is evident that the dysfunction of the Wnt/ $\beta$-catenin signaling pathway is associated with the pathogenesis of HCC [43]. Guichard et al. showed that the Wnt/ $\beta$-catenin signaling pathway might involve in the oncogenesis of HCC since it is related to both oxidative stress metabolism and Ras/mitogen-activated protein kinase pathways [44]. Similar to the expression of TLR4, our study provided an evidence that the expression

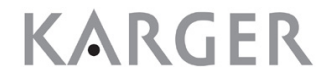




\section{Cellular Physiology Cell Physiol Biochem 2017;42:469-479 \begin{tabular}{l|l} 
DOI: 10.1159/000477594 & O 2017 The Author(s). Published by S. Karger AG, Basel \\
www.karger.com/cpb
\end{tabular}}

Yin et al.: Impact of TLR4 on the Development of HBV-Related HCC

of $\beta$-catenin in HCC tissues were significantly higher than that in normal liver tissues. Our study also revealed that down-regulated $\beta$-catenin induced cell apoptosis but inhibited the proliferation, immigration and invasion of HepG2.2.15 cells. The above conclusion is also supported by our in vivo experiments which concluded that $\beta$-catenin has potential modulating effects on HBV-related HCC. Therefore, we suspected that TLR4 directly activated Wnt/ $\beta$-catenin signaling pathway. As suggested by our in vivo and in vitro experiments, TLR4 could increase the expression of $\beta$-catenin and antagonize the inhibitory effects of $\beta$-catenin siRNA on HCC cells to a certain degree. Therefore, we verified the hypothesis that TLR4 triggers the activation of downstream $\beta$-catenin. Santaolalla et al. demonstrated that TLR4 activated $\beta$-catenin through an intracellular signaling pathway resulting in the occurrence and development of intestinal neoplasia [20].

However, some contradictory results have been found in the current literature. For instance, Sodhi et al. indicated that TLR4 inhibited $\beta$-catenin and depressed enterocyte proliferation by conducting experiments on mice in which the necrotizing enterocolitis model was established [45]. Therefore, the effect of TLR4 on tumor progression may depend on cell types as well as external environment which may modulate the proliferation and metastasis of tumor cells. Hence, further investigations are essential to clarify these contradictions. Moreover, some previous studies reported that the $\beta$-catenin regulation by TLR4 required the activation of TLR4 via LPS and the dependence of PI3K [20,39], whereas this study didn't take these factors into consideration.

Overall, our study confirmed that TLR4 could increase the expression of $\beta$-catenin, stimulate the proliferation and invasion of tumor cells and have impact on the progression of HBV-related HCC. As a result, both TLR4 and Wnt/ $\beta$-catenin pathway may be considered as potential molecular targets for the treatments of patients with HBV-related HCC.

\section{Disclosure Statement}

The authors declare no conflict of interest.

\section{References}

1 El-Serag HB: Hepatocellular carcinoma. N Engl J Med 2011;365:1118-1127.

-2 Forner A, Llovet JM, Bruix J: Hepatocellular carcinoma. Lancet 2012;379:1245-1255.

3 Bodzin AS, Busuttil RW: Hepatocellular carcinoma: Advances in diagnosis, management, and long term outcome. World J Hepatol 2015;7:1157-1167.

4 Gao JJ, Shi ZY, Xia JF, Inagaki Y, Tang W: Sorafenib-based combined molecule targeting in treatment of hepatocellular carcinoma. World J Gastroenterol 2015;21:12059-12070.

5 Gollob JA, Wilhelm S, Carter C, Kelley SL: Role of Raf kinase in cancer: therapeutic potential of targeting the Raf/MEK/ERK signal transduction pathway. Semin Oncol 2006;33:392-406.

-6 Arzumanyan A, Reis HM, Feitelson MA: Pathogenic mechanisms in HBV- and HCV-associated hepatocellular carcinoma. Nat Rev Cancer 2013;13:123-135.

7 Whittaker S, Marais R, Zhu AX: The role of signaling pathways in the development and treatment of hepatocellular carcinoma. Oncogene 2010;29:4989-5005.

8 Iwasaki A, Medzhitov R: Toll-like receptor control of the adaptive immune responses. Nat Immunol 2004;5:987-995.

9 Geisse J, Caro I, Lindholm J, Golitz L, Stampone P, Owens M: Imiquimod 5\% cream for the treatment of superficial basal cell carcinoma: results from two phase III, randomized, vehicle-controlled studies. J Am Acad Dermatol 2004;50:722-733.

10 Meraldi V, Audran R, Romero JF, Brossard V, Bauer J, Lopez JA, Corradin G: OM-174, a new adjuvant with a potential for human use, induces a protective response when administered with the synthetic C-terminal fragment 242-310 from the circumsporozoite protein of Plasmodium berghei. Vaccine 2003;21:2485-2491. 


\section{Cellular Physiology Cell Physiol Biochem 2017;42:469-479 \begin{tabular}{l|l} 
DOI: 10.1159/000477594 & Ond 2017 The Author(s). Published by S. Karger AG, Basel \\
www.karger.com/cpb
\end{tabular}}

Yin et al.: Impact of TLR4 on the Development of HBV-Related HCC

11 Ma F, Zhang J, Zhang C: The TLR7 agonists imiquimod and gardiquimod improve DC-based immunotherapy for melanoma in mice. Cell Mol Immunol 2010;7:381-388.

-12 Szczepanski MJ, Czystowska M, Szajnik M, Harasymczuk M, Boyiadzis M, Kruk-Zagajewska A, Szyfter W, Zeromski J, Whiteside TL: Triggering of Toll-like receptor 4 expressed on human head and neck squamous cell carcinoma promotes tumor development and protects the tumor from immune attack. Cancer Res 2009;69:3105-3113.

13 Lin A, Wang G, Zhao H, Zhang Y, Han Q, Zhang C, Tian Z, Zhang J: TLR4 signaling promotes a COX-2/PGE/ STAT3 positive feedback loop in hepatocellular carcinoma (HCC) cells. Oncoimmunology 2016;5:e1074376.

14 Dapito DH, Mencin A, Gwak GY, Pradere JP, Jang MK, Mederacke I, Caviglia JM, Khiabanian H, Adeyemi A, Bataller R, Lefkowitch JH, Bower M, Friedman R, Sartor RB, Rabadan R, Schwabe RF: Promotion of hepatocellular carcinoma by the intestinal microbiota and TLR4. Cancer Cell 2012;21:504-516.

15 Clevers H, Nusse R: Wnt/beta-catenin signaling and disease. Cell 2012;149:1192-1205.

16 Giles RH, van Es JH, Clevers H: Caught up in a Wnt storm: Wnt signaling in cancer. Biochim Biophys Acta 2003;1653:1-24.

17 Polakis P: Wnt signaling and cancer. Genes Dev 2000;14:1837-1851.

18 Anastas JN, Moon RT: WNT signalling pathways as therapeutic targets in cancer. Nat Rev Cancer 2013;13:11-26.

19 Kim M, Lee HC, Tsedensodnom 0, Hartley R, Lim YS, Yu E, Merle P, Wands JR: Functional interaction between Wnt3 and Frizzled-7 leads to activation of the Wnt/beta-catenin signaling pathway in hepatocellular carcinoma cells. J Hepatol 2008;48:780-791.

20 Santaolalla R, Sussman DA, Ruiz JR, Davies JM, Pastorini C, Espana CL, Sotolongo J, Burlingame O, Bejarano PA, Philip S, Ahmed MM, Ko J, Dirisina R, Barrett TA, Shang L, Lira SA, Fukata M, Abreu MT: TLR4 activates the beta-catenin pathway to cause intestinal neoplasia. PLoS One 2013;8:e63298.

21 Fu J, Zhang Z, Zhou L, Qi Z, Xing S, Lv J, Shi J, Fu B, Liu Z, Zhang JY, Jin L, Zhao Y, Lau GK, Zhao J, Wang FS: Impairment of CD4+ cytotoxic $\mathrm{T}$ cells predicts poor survival and high recurrence rates in patients with hepatocellular carcinoma. Hepatology 2013;58:139-149.

-22 Wang ZS, Wu LQ Yi X, Geng C, Li YJ, Yao RY: Connexin-43 can delay early recurrence and metastasis in patients with hepatitis B-related hepatocellular carcinoma and low serum alpha-fetoprotein after radical hepatectomy. BMC Cancer 2013;13:306.

23 El-Serag HB, Rudolph KL: Hepatocellular carcinoma: epidemiology and molecular carcinogenesis. Gastroenterology 2007;132:2557-2576.

24 Hagemann T, Balkwill F, Lawrence T: Inflammation and cancer: a double-edged sword. Cancer Cell 2007;12:300-301.

-25 Ferrone C, Dranoff G: Dual roles for immunity in gastrointestinal cancers. J Clin Oncol 2010;28:4045-4051.

26 Kumar H, Kawai T, Akira S: Toll-like receptors and innate immunity. Biochem Biophys Res Commun 2009;388:621-625.

27 Krishnan J, Selvarajoo K, Tsuchiya M, Lee G, Choi S: Toll-like receptor signal transduction. Exp Mol Med 2007;39:421-438.

-28 Akira S, Yamamoto M, Takeda K: Role of adapters in Toll-like receptor signalling. Biochem Soc Trans 2003;31:637-642.

29 Fernandez-Garcia B, Eiro N, Gonzalez-Reyes S, Gonzalez L, Aguirre A, Gonzalez LO, Del Casar JM, GarciaMuniz JL, Vizoso FJ: Clinical significance of toll-like receptor 3, 4, and 9 in gastric cancer. J Immunother 2014;37:77-83.

-30 Sussman DA, Santaolalla R, Bejarano PA, Garcia-Buitrago MT, Perez MT, Abreu MT, Clarke J: In silico and Ex vivo approaches identify a role for toll-like receptor 4 in colorectal cancer. J Exp Clin Cancer Res 2014;33:45.

31 Meng X, Liu Y, Liu B: Glutathione S-transferase M1 null genotype meta-analysis on gastric cancer risk. Diagn Pathol 2014;9:122.

-32 Li D, Jin Y, Sun Y, Lei J, Liu C: Knockdown of toll-like receptor 4 inhibits human NSCLC cancer cell growth and inflammatory cytokine secretion in vitro and in vivo. Int J Oncol 2014;45:813-821.

33 Yuan X, Zhou Y, Wang W, Li J, Xie G, Zhao Y, Xu D, Shen L: Activation of TLR4 signaling promotes gastric cancer progression by inducing mitochondrial ROS production. Cell Death Dis 2013;4:e794. 


\section{Cellular Physiology Cell Physiol Biochem 2017;42:469-479 \begin{tabular}{l|l} 
DOI: 10.1159/000477594 & Ond Biochemistry 2017 The Author(s). Published by S. Karger AG, Basel \\
www.karger.com/cpb
\end{tabular}}

Yin et al.: Impact of TLR4 on the Development of HBV-Related HCC

34 Li Y, Teo WL, Low MJ, Meijer L, Sanderson I, Pettersson S, Greicius G: Constitutive TLR4 signalling in intestinal epithelium reduces tumor load by increasing apoptosis in APC(Min/+) mice. Oncogene 2014;33:369-377.

35 Soares JB, Pimentel-Nunes P, Afonso L, Rolanda C, Lopes P, Roncon-Albuquerque R, Jr., Goncalves N, BoalCarvalho I, Pardal F, Lopes S, Macedo G, Lara-Santos L, Henrique R, Moreira-Dias L, Goncalves R, DinisRibeiro M, Leite-Moreira AF: Increased hepatic expression of TLR2 and TLR4 in the hepatic inflammationfibrosis-carcinoma sequence. Innate Immun 2012;18:700-708.

-36 Wang Z, Yan J, Lin H, Hua F, Wang X, Liu H, Lv X, Yu J, Mi S, Wang J, Hu ZW: Toll-like receptor 4 activity protects against hepatocellular tumorigenesis and progression by regulating expression of DNA repair protein Ku70 in mice. Hepatology 2013;57:1869-1881.

-37 Wang L, Zhu R, Huang Z, Li H, Zhu H: Lipopolysaccharide-induced toll-like receptor 4 signaling in cancer cells promotes cell survival and proliferation in hepatocellular carcinoma. Dig Dis Sci 2013;58:2223-2236.

38 Gu J, Sun R, Shen S, Yu Z: The influence of TLR4 agonist lipopolysaccharides on hepatocellular carcinoma cells and the feasibility of its application in treating liver cancer. Onco Targets Ther 2015;8:2215-2225.

-39 Jing YY, Han ZP, Sun K, Zhang SS, Hou J, Liu Y, Li R, Gao L, Zhao X, Zhao QD, Wu MC, Wei LX: Toll-like receptor 4 signaling promotes epithelial-mesenchymal transition in human hepatocellular carcinoma induced by lipopolysaccharide. BMC Med 2012;10:98.

40 Logan CY, Nusse R: The Wnt signaling pathway in development and disease. Annu Rev Cell Dev Biol 2004;20:781-810.

41 Cheon SS, Nadesan P, Poon R, Alman BA: Growth factors regulate beta-catenin-mediated TCF-dependent transcriptional activation in fibroblasts during the proliferative phase of wound healing. Exp Cell Res 2004;293:267-274.

42 Clevers H: Wnt/beta-catenin signaling in development and disease. Cell 2006;127:469-480.

-43 Bengochea A, de Souza MM, Lefrancois L, Le Roux E, Galy O, Chemin I, Kim M, Wands JR, Trepo C, Hainaut P, Scoazec JY, Vitvitski L, Merle P: Common dysregulation of Wnt/Frizzled receptor elements in human hepatocellular carcinoma. Br J Cancer 2008;99:143-150.

44 Guichard C, Amaddeo G, Imbeaud S, Ladeiro Y, Pelletier L, Maad IB, Calderaro J, Bioulac-Sage P, Letexier M, Degos F, Clement B, Balabaud C, Chevet E, Laurent A, Couchy G, Letouze E, Calvo F, Zucman-Rossi J: Integrated analysis of somatic mutations and focal copy-number changes identifies key genes and pathways in hepatocellular carcinoma. Nat Genet 2012;44:694-698.

-45 Sodhi CP, Shi XH, Richardson WM, Grant ZS, Shapiro RA, Prindle T, Jr., Branca M, Russo A, Gribar SC, Ma C, Hackam DJ: Toll-like receptor-4 inhibits enterocyte proliferation via impaired beta-catenin signaling in necrotizing enterocolitis. Gastroenterology 2010;138:185-196. 